\title{
Attenuation of Cf-Mediated Defense Responses at Elevated Temperatures Correlates With a Decrease in Elicitor-Binding Sites
}

\author{
Camiel F. de Jong, Frank L. W. Takken, Xinzhong Cai, Pierre J. G. M. de Wit, and \\ Matthieu H. A. J. Joosten \\ Laboratory of Phytopathology, Wageningen University, Binnenhaven 5, 6709 PD Wageningen, The Netherlands \\ Submitted 29 March 2002. Accepted 10 June 2002.
}

The interaction between the fungal pathogen Cladosporium fulvum and its only host, tomato, is a well-described genefor-gene system and several resistance $(C f)$ genes of tomato and matching fungal avirulence (Avr) genes have been characterized. Transgenic tobacco suspension cells expressing $C f$ genes respond to matching elicitors with typical defense responses, such as medium alkalization and an oxidative burst. We found that this response is attenuated at elevated ambient temperatures. Tomato seedlings expressing both a $C f$ and the matching $A v r$ gene rapidly die as a result of systemic necrosis at normal temperatures, but are rescued at $33^{\circ} \mathrm{C}$. We demonstrate that, at $33^{\circ} \mathrm{C}$, the $C f / A v r$ mediated induction of defense-related genes is reversibly suppressed. Furthermore, in cell suspensions, the AVR-induced medium alkalization response is slowly suppressed upon incubation at $33^{\circ} \mathrm{C}$, but is quickly restored after transfer to lower temperatures. A high-affinity binding site (HABS) for AVR9 is present on plasma membranes isolated from solanaceous plants and has been suggested to act as a co-receptor for AVR9. The amount of AVR9-HABS is $80 \%$ reduced in tobacco cell suspensions incubated at $33^{\circ} \mathrm{C}$, as compared with cell suspensions incubated at $20^{\circ} \mathrm{C}$. Our data suggest that the temperature sensitivity of $C f$-mediated defense responses resides at the level of perception of the fungal avirulence factors.

Additional keywords: hypersensitive response, recognition.

Plants are constantly challenged by various pathogens, such as viruses, bacteria, fungi, nematodes, and insects. To cope with these foes, plants have developed mechanisms to recognize invading pathogens and subsequently mount active defense responses. In the gene-for-gene model as described by Flor (1942), a plant resistance $(R)$ gene confers resistance to strains of a pathogen that express the matching avirulence ( $A v r$ ) gene. $R$ gene-mediated recognition of an Avr gene product results in several biochemical and physiological responses that eventually

Corresponding author: M. H. A. J. Joosten; Telephone +31 317 483411; Fax: +31 317483412 ; E-mail: matthieu.joosten@wur.nl.

Current address of F. L. W. Takken: University of Amsterdam, Swammerdam Institute of Life Sciences, Plant Pathology, Kruislaan 318, 1098 SM Amsterdam, The Netherlands.

Current address of X. Cai: Department of Plant Protection, College of Agriculture and Biotechnology, Zhejiang University, Hua Jia Chi Campus, 268 Kaixuan Road, Hangzhou 310029, China. culminate into a hypersensitive response (HR), resulting in an arrest of growth of the invading pathogen (Dixon et al. 1994; May et al. 1996).

Over the last years, several $A v r$ s and their matching $R$ genes have been cloned and characterized. Avr genes encode a very diverse array of proteins (Bonas and Van den Ackerveken 1999; Joosten and De Wit 1999; Laugé and De Wit 1998; Padgett et al. 1997). In contrast, most $R$ genes encode receptorlike proteins that contain leucine-rich repeats (LRRs), which are thought to be involved in protein-protein or receptorligand interactions (Bent 1996; Hammond-Kosack and Jones 1997; Jones and Jones 1997). Overall, R proteins may be divided into three main classes: (i) receptor-like protein kinases, (ii) nucleotide-binding site (NBS)-LRR proteins, and (iii) proteins with an extracellular domain containing LRRs and a small cytoplasmic region without any putative signaling domain (Takken and Joosten 2000). The structure of $\mathrm{R}$ proteins suggests a role as receptor for AVRs. Therefore, it is surprising that, to date, only in a few cases a direct interaction between an R protein and an AVR has been described (Jia et al. 2000; Tang et al. 1996).

An intensively studied gene-for-gene system is the interaction between the leaf mold pathogen Cladosporium fulvum and its only host, tomato (Joosten and De Wit 1999). From this pathosystem, the matching resistance $(C f)$ and $A v r$ gene pairs Cf-9/Avr9 (Jones et al. 1994; Van Kan et al. 1991), Cf-4/Avr4 (Joosten et al. 1994; Thomas et al. 1997), Cf-2/Avr2 (Dixon et al. 1996; Luderer et al. 2002), and Cf-4E/Avr4E (Takken et al. 1998; N. Westerink, B. Brandwagt, P. de Wit, and M. Joosten, unpublished data), have been characterized. The $C f$ genes are structurally similar to the proteins encoded by the tomato Ve genes, which confer resistance against Verticillium species (Kawchuk et al. 2001) and encode membrane-anchored receptor-like proteins that belong to the third class of LRR resistance proteins.

The lack of a cytoplasmic signaling domain suggests that the signaling function might be performed by a third component that interacts with the Cf protein (Joosten and De Wit 1999). Binding studies performed with ${ }^{125}$ I-AVR9 on plasma membranes isolated from tomato leaves revealed the presence of a high-affinity binding site (HABS) for this peptide (Kooman-Gersmann et al. 1996). Interestingly, the HABS proved to be present on plasma membranes isolated from tomato leaves both lacking and containing $C f-9$. This indicates that the Cf-9 protein confers the ability to recognize AVR9 to the plant but does not represent the HABS itself, and is not required for AVR9 binding to the HABS. In tomato plants containing $C f-9$, for various mutant AVR9 peptides, a clear posi- 
tive correlation between HR-inducing activity and affinity for the HABS has been found, indicating that the HABS plays an essential role in AVR9 perception (Kooman-Gersmann et al. 1998). Further studies revealed that the HABS was present in all solanaceous species tested (Kooman-Gersmann et al. 1996). The Cf-9 protein was produced in various heterologous expression systems and was analyzed for AVR9-binding affinity (Luderer et al. 2001). Although various techniques were employed to detect possible binding of AVR9 to Cf-9, no direct interaction between the two proteins could be detected. Transfer of $C f-9$ to other solanaceous plants that contain the HABS confers the ability to recognize AVR9 (HammondKosack et al. 1998; Van der Hoorn et al. 2000). Together with the lack of a direct binding of AVR9 to Cf-9, this suggests that the HABS may well be the AVR9 co-receptor that interacts with Cf-9 (Jones and Jones 1997; Joosten and De Wit 1999).

$C f$-9-containing tomato cell suspensions do not respond to AVR9 (Honée et al. 1998). However, AVR9-treated $C f-9^{+}$ transgenic tobacco cell suspensions do show typical defense responses, such as medium alkalization and an oxidative burst. Furthermore, activation of MAP kinases, a calcium-dependent protein kinase (CDPK), and cell death occurred (de Jong et al. 2000; Piedras et al. 1998; Romeis et al. 1999, 2000). When experiments were performed on the bench rather than in a climate chamber, we observed that, during warm days, AVR9-induced early defense responses in such transgenic $\mathrm{Cf}-9^{+}$ tobacco cell suspensions were significantly attenuated. Temperature sensitivity also has been observed for other $R$ genes. A classical example of temperature-sensitivity of resistance responses in solanaceous plant species is the resistance response to Tobacco mosaic virus (TMV) as conferred by the $N$ gene of tobacco (Samuel 1931). Below $28^{\circ} \mathrm{C}$, the $N$ gene mediates resistance by specific recognition of the helicase of TMV (Padgett et al. 1997); whereas, above this temperature, the virus is able to infect the plant systemically. Although numerous examples of temperature-sensitive resistance have been described, the biochemical basis of this phenomenon is far from clear (Dropkin 1969; Loegering and Giss 1957; Samuel 1931)

The availability of various matching Cf/Avr combinations and a very sensitive biological system provides us with the tools to study the various steps of the AVR-induced HR, from an event as early as AVR perception until its actual execution. This enabled us to systematically examine the effect of elevated temperatures on individual links in the chain of events leading from AVR perception to HR. Here we demonstrate that tomato seedlings, expressing both an Avr of C. fulvum and the matching $C f$ gene, die due to systemic $\mathrm{HR}$ at $20^{\circ} \mathrm{C}$ and are rescued at $33^{\circ} \mathrm{C}$. Transfer of rescued seedlings to $20^{\circ} \mathrm{C}$ quickly results in induction of defense-related genes and subsequent development of systemic HR. Furthermore, in $C f$-transgenic tobacco cell suspensions, AVR-induced defense responses were efficiently suppressed at $33^{\circ} \mathrm{C}$. Finally, we demonstrate that binding of ${ }^{125} \mathrm{I}-\mathrm{AVR} 9$ to microsomal fractions isolated from cell suspensions incubated at $33^{\circ} \mathrm{C}$ was significantly reduced compared with cells incubated at $20^{\circ} \mathrm{C}$. The implications of these findings are discussed.

\section{RESULTS}

\section{Tomato seedlings expressing}

\section{matching $C f$ and $A v r$ genes are rescued at $33^{\circ} \mathrm{C}$.}

Seed was obtained from a cross between Moneymaker (MM)-Cf4 and MM-Cf0 tomato plants expressing Avr4 (Avr4 ${ }^{+}$ MM-Cf0), and from a cross between MM-Cf9 and MM-Cf0 plants expressing Avr9 (Avr $9^{+}$MM-Cf0). Under standard greenhouse conditions these $C f-4 / A v r 4$ and $C f$-9/Avr 9 seed readily germinate but develop a systemic HR within 2 to 4 days post emergence of the hypocotyls (Cai et al. 2001; Hammond-Kosack et al. 1994; Thomas et al. 1997). To test for a possible temperature sensitivity of Cf/AVR-mediated HR, the $C f / A v r$ seed were sown under standard greenhouse conditions, after which the seedlings were transferred to 20 or $33^{\circ} \mathrm{C}$ immediately upon emergence of the hypocotyls. After 3 weeks at $20^{\circ} \mathrm{C}$, the $C f-4 / A v r 4$ seedlings had become completely necrotic, whereas the controls, Avr4 ${ }^{+}$MM-Cf0 and MM-Cf4, developed normally (Fig. 1A). In contrast, upon incubation at $33^{\circ} \mathrm{C}$, the $C f-4 / A v r 4$ seedlings did not show any HR (Fig. 1B).

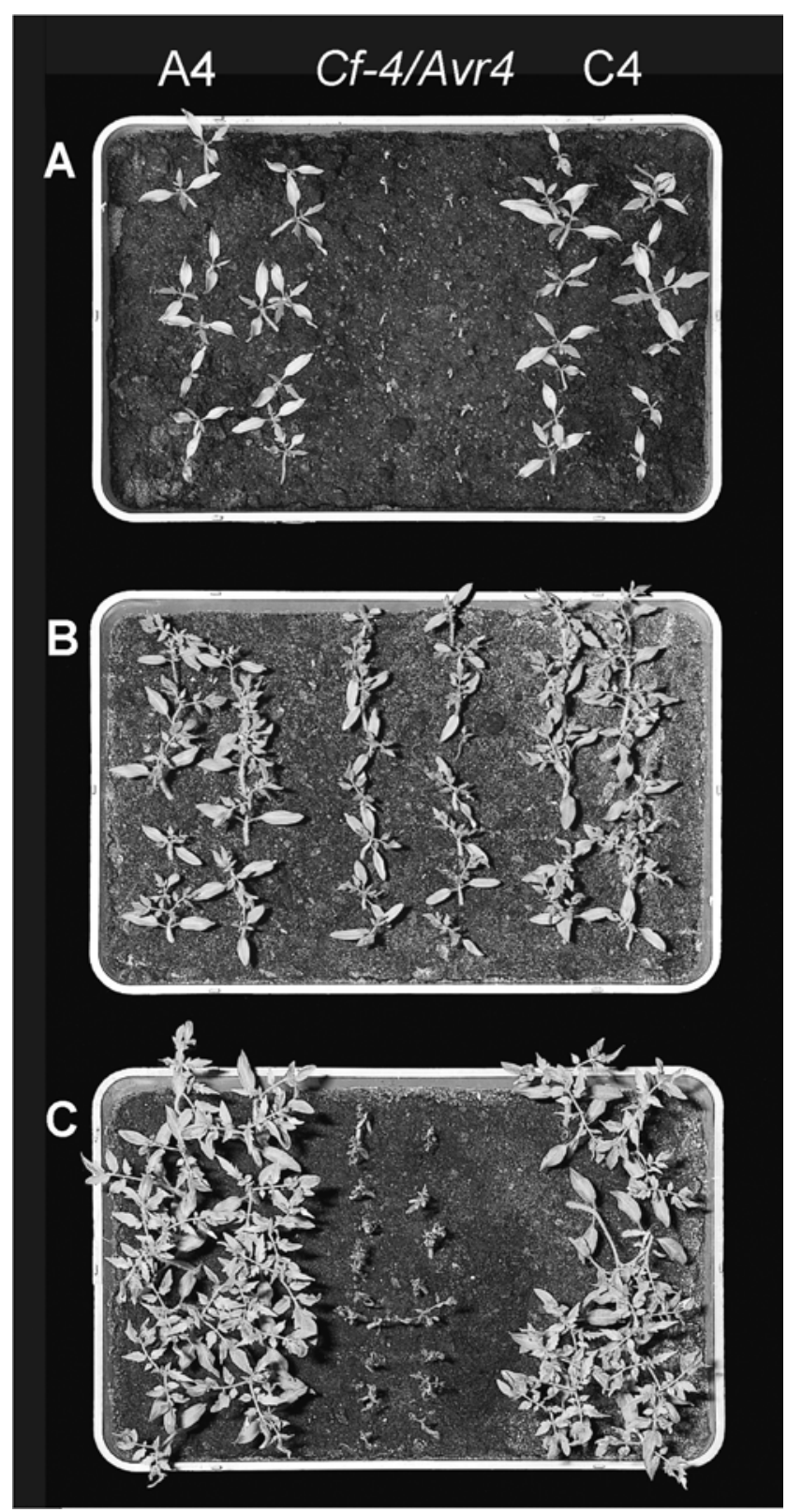

Fig. 1. Rescue of Moneymaker (MM)-Cf4 seedlings expressing avirulence gene Avr4 at $33^{\circ} \mathrm{C}$. Seeds of $A v r 4^{+}$MM-CfO, MM-Cf4, and Cf-4/Avr4 were sown under standard greenhouse conditions and, after emergence of the hypocotyls, the seedlings were incubated at 20 or $33^{\circ} \mathrm{C}$ for 3 weeks Seedlings that had been incubated at $33^{\circ} \mathrm{C}$ were eventually transferred to $20^{\circ} \mathrm{C}$. A, At $20^{\circ} \mathrm{C}, \mathrm{Cf}-4 / \mathrm{Av} r 4$ seedlings die within 1 week after emergence of the hypocotyls, whereas Avr4+ MM-Cf0 (A4) and MM-Cf4 (C4) seedlings develop normally. The photograph was taken 3 weeks after sowing. B, At $33^{\circ} \mathrm{C}$, all seedlings, including the ones expressing both $C f-4$ and Avr4, develop normally. The photograph was taken 4 weeks after sowing. C, Upon transfer from 33 to $20^{\circ} \mathrm{C}, C f$-4/Avr4 seedlings develop systemic hypersensitive response, resulting in death within 3 days after transfer. The photograph was taken 3 days after transfer to $20^{\circ} \mathrm{C}$. 
All seedlings grown at $33^{\circ} \mathrm{C}$ were somewhat retarded in growth compared with the control seedlings grown at $20^{\circ} \mathrm{C}$ (data not shown). Transfer of the rescued Cf-4/Avr4 seedlings from 33 to $20^{\circ} \mathrm{C}$ resulted in the development of visible $\mathrm{HR}$ symptoms within $12 \mathrm{~h}$, followed by death of the plants within 3 days (Fig. 1C). Similar results were obtained for tomato seedlings expressing both $C f-9$ and $A v r 9$ (data not shown).

\section{AVR-induced expression of defense-related genes is reversibly suppressed at $33^{\circ} \mathrm{C}$.}

The results presented above demonstrate that, at $33^{\circ} \mathrm{C}$, the development of HR in plants expressing both a $C f$ gene and the matching Avr gene is suppressed. To test whether the expression of defense-related genes also is affected, the expression level of genes involved in HR ( LeHsr203), defense signaling $(C D P K, N P R 1$, and $A C C O X)$, or defense responses (P69, ChiA, ChiB, GluA, GluB, and LTP) (Cai et al. 2001) was

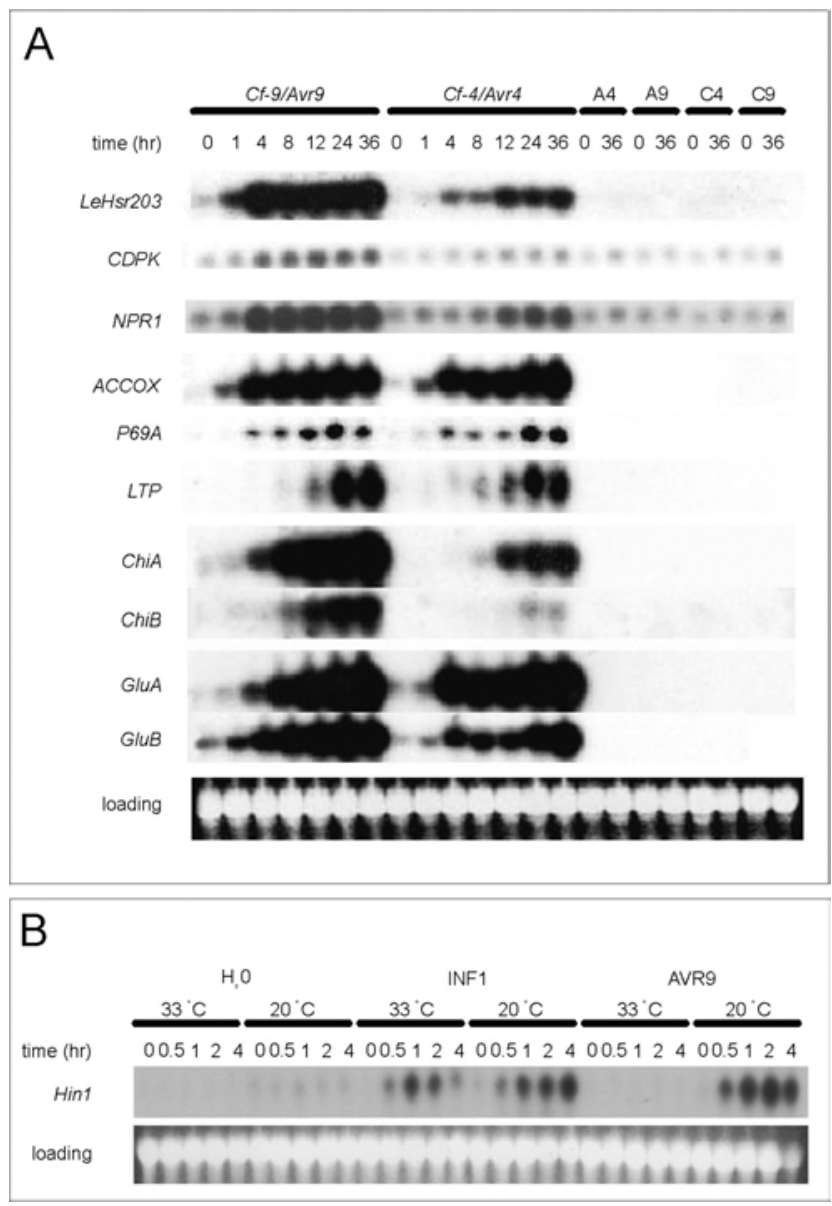

Fig. 2. Induction of defense-related gene expression in tomato seedlings and tobacco cell suspensions. A, Tomato seed of Cf-9/Avr $9, C f-4 / A v r 4$, $A v r 4^{+}$Moneymaker (MM)-Cf0 (A4), Avr $9^{+}$MM-Cf0 (A9), MM-Cf4 (C4), and MM-Cf9 (C9) were planted under normal greenhouse conditions. After emergence of the hypocotyls, the seedlings were incubated at $33^{\circ} \mathrm{C}$ for 2 weeks. Seedlings were subsequently transferred to $20^{\circ} \mathrm{C}$ and RNA was isolated for gel blot analysis at $0,1,4,8,12,24$, and $36 \mathrm{~h}$ after transfer. The controls, A4, A9, C4, and C9 were sampled only at 0 and 36 $\mathrm{h}$ after transfer. The blots were hybridized with probes derived from defense-related genes as indicated in the left margin. The panel labeled "loading" shows the ethidium bromide-stained 18S ribosomal RNA. B, $C f-9^{+}-$tobacco cell suspensions were incubated at 33 or $20^{\circ} \mathrm{C}$ for $24 \mathrm{~h}$ and subsequently were treated with INF1 or AVR9, both at a final concentration of $0.32 \mu \mathrm{M}$, or water. At $0,0.5,1,2$, and $4 \mathrm{~h}$ after treatment, RNA was isolated, separated on gel, and probed with the hypersensitive response marker Hinl. The panel labeled "loading" shows the ethidium bromide-stained $18 \mathrm{~S}$ ribosomal RNA. determined at different time points after transfer of CflAvr seedlings from 33 to $20^{\circ} \mathrm{C}$. At $33^{\circ} \mathrm{C}$ (time $[t]=0$ ), the expression level of the various classes of genes was similar to that of the control plants (Fig. 2A). However, within 1 to $8 \mathrm{~h}$ after transfer to $20^{\circ} \mathrm{C}$, the expression of LeHsr203, CDPK, NPRl, $A C C O X, P 69$, ChiA, GluA, and GluB was specifically induced in $C f / A v r$ seedlings. The expression of $L T P$ and $C h i B$ was induced at later stages. In $C f-4 / A v r 4$ seedlings, expression of most of the genes appeared to be induced somewhat later compared with $C f-9 / A v r 9$ seedlings $(t=36 \mathrm{~h}$, Fig. 2A). The controls, $A v r 4^{+}$MM-Cf0, Avr $9^{+}$MM-Cf0, MM-Cf4, and MM-Cf9, did not show induction of gene expression after transfer to $20^{\circ} \mathrm{C}$ (Fig. 2A). Thus, the expression of the various defenserelated genes is specifically induced upon activation of the HR and not by the temperature shift itself.

\section{In tobacco cell suspensions, AVR-induced} defense responses also are suppressed at $33^{\circ} \mathrm{C}$.

$C f-9^{+}$-tobacco cell suspensions have been shown to be a very suitable system to study the characteristics of early AVR9-induced defense responses (de Jong et al. 2000; Piedras et al. 1998). To test whether HR-related gene expression is still induced at $33^{\circ} \mathrm{C}, C f-9^{+}$-tobacco cell suspensions were incubated at 20 or $33^{\circ} \mathrm{C}$ for $24 \mathrm{~h}$ and subsequently treated with AVR9 or INF1. INF1 is an elicitor of the oomycete pathogen Phytophthora infestans, to which tobacco is responsive (Kamoun et al. 1998). RNA gel blot analysis revealed that, at $20^{\circ} \mathrm{C}$, expression of the HR marker Hinl is strongly induced by INF1 or AVR9, within 30 min after addition of the elicitor (Fig. 2B). At $33^{\circ} \mathrm{C}$, however, no induction of Hinl expression is observed upon AVR9 treatment, whereas INF1 still induces expression of this gene, indicating that the cells are viable and still are able to mount a defense response at this temperature. The tobacco homologue of LeHsr203 also was tested, but this gene was already highly expressed in untreated $C f-9^{+}$-tobacco cell suspensions at $20^{\circ} \mathrm{C}$ (data not shown). PR genes, such as $C h i A$ and $C h i B$, were also already highly expressed in the control treatments at $20^{\circ} \mathrm{C}$. Interestingly, background expression of these genes was attenuated at $33^{\circ} \mathrm{C}$ (results not shown). Vitality stains (Oparka and Read 1994) demonstrated that the viability of cells incubated for $24 \mathrm{~h}$ at $33^{\circ} \mathrm{C}$ was similar to that of cells incubated at $25^{\circ} \mathrm{C}$, which is the standard temperature at which the cell suspensions are maintained. Furthermore, the fresh weight of the cells during incubation at $33^{\circ} \mathrm{C}$ increased progressively, indicating that the cells were healthy and multiplying at this temperature (data not shown).

\section{AVR- but not INF1-induced medium alkalization is reversibly suppressed}

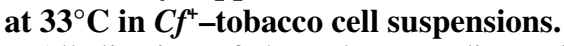

Alkalization of the culture medium of cell suspensions is one of the earliest responses induced after elicitor treatment (de Jong et al. 2000; Piedras et al. 1998). To extend our studies on the temperature-sensitivity of early defense-related responses, we also generated $C f-4^{+}$-tobacco cell suspensions. Upon treatment with AVR4, these cells specifically reacted with medium alkalization and an oxidative burst. To assess whether AVR-induced medium alkalization also is suppressed at $33^{\circ} \mathrm{C}, C f-4^{+}-$and $C f-9^{+}$-tobacco cell suspensions were incubated for $24 \mathrm{~h}$ at either 25 or $33^{\circ} \mathrm{C}$, after which they were treated with the matching AVR or INF1. At $25^{\circ} \mathrm{C}$, treatment with the matching AVR or INF1 results in a rapid increase of the $\mathrm{pH}$ of the culture medium (Fig. $3 \mathrm{~A}$ and $\mathrm{B}$ ). At $33^{\circ} \mathrm{C}$, however, the AVR-induced response is completely suppressed (Fig. $3 \mathrm{C}$ and $\mathrm{D}$ ), whereas the response of the cells upon challenge with INF1 is reduced to approximately 50\%. The slight increase in $\mathrm{pH}$ that is observed after AVR4 treatment at $33^{\circ} \mathrm{C}$ 


\section{$C f-4^{+}$tobacco cell suspension}

\section{Cf $-9^{+}$tobacco cell suspension}
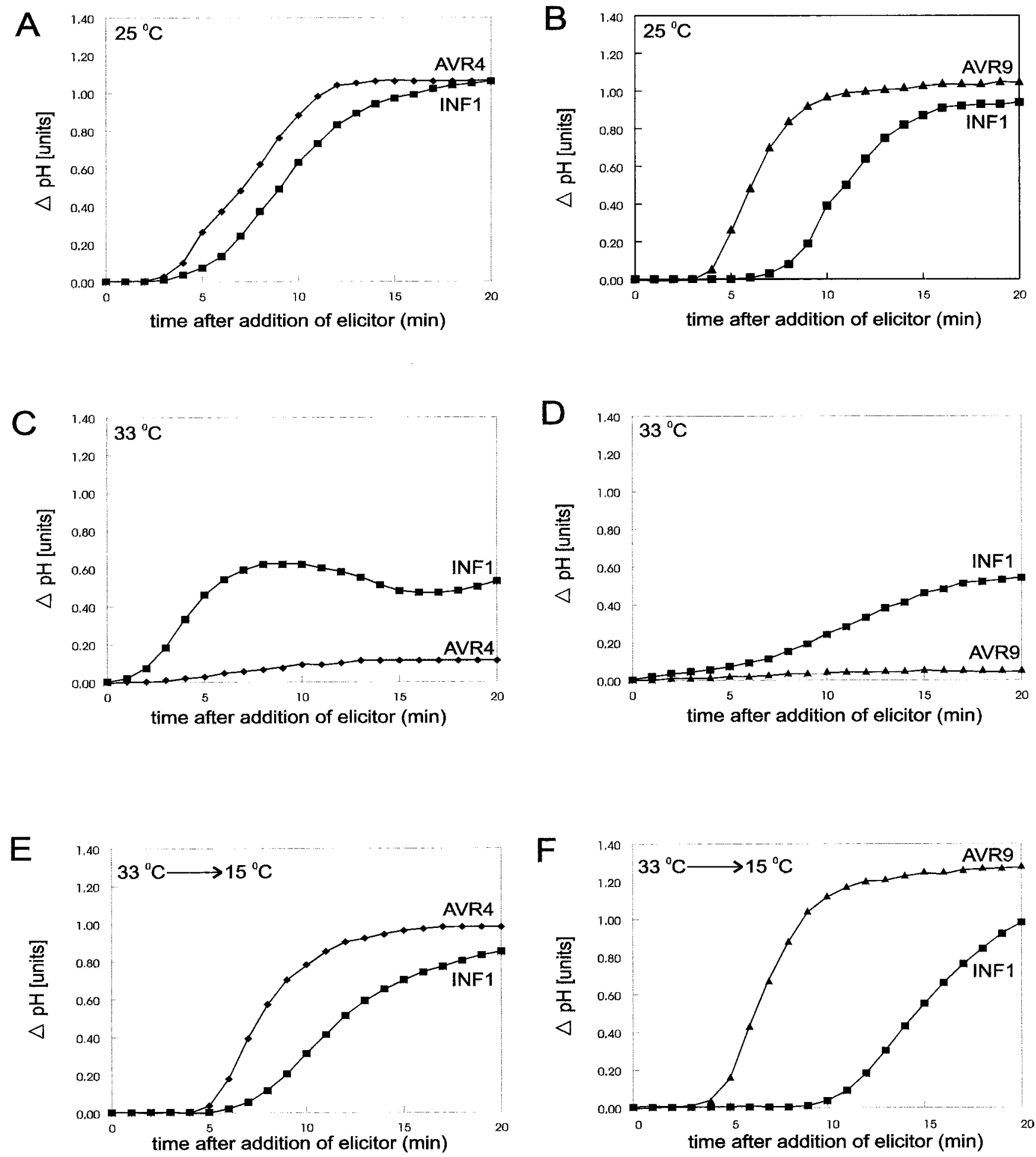

Fig. 3. Cladosporium fulvum avirulence protein (AVR)- but not INF1-induced medium alkalization in $C f^{4}$-tobacco cell suspensions is reversibly suppressed at elevated temperature. To assess whether AVR-induced medium alkalization is suppressed at $33^{\circ} \mathrm{C}, C f-4^{+}-$and $C f-9^{+}$-tobacco cell suspensions were incubated at either 25 or $33^{\circ} \mathrm{C}, 3$ days after subculturing. After $24 \mathrm{~h}$ of incubation, cell suspensions were treated with the matching AVR (AVR4 [ $\bullet$ or AVR9 $[\boldsymbol{\Delta}])$ and INF1 (ם) and the $\mathrm{pH}$ of the extracellular medium was recorded. To assay for recovery of the medium alkalization response, cells incubated at $33^{\circ} \mathrm{C}$ without elicitor treatment were transferred to $15^{\circ} \mathrm{C}$. After incubation for $15 \mathrm{~h}$, cells were treated with the matching AVR or INF1 and the pH of the extracellular medium was recorded. A, AVR4- and INF1-induced response of $C f-4^{+}$cells at $25^{\circ} \mathrm{C}$. B, AVR9- and INF1-induced response of $C f-9^{+}$cells at $25^{\circ} \mathrm{C}$. C, AVR4- and INF1-induced response of $C f-4^{+}$cells after preincubation for $24 \mathrm{~h}$ at $33^{\circ} \mathrm{C}$. D, AVR9- and INF1-induced response of $C f-9^{+}$cells after preincubation for $24 \mathrm{~h}$ at $33^{\circ} \mathrm{C}$. E, AVR4- and INF1-induced response of $C f-4^{+}$cells after transfer from 33 to $15^{\circ} \mathrm{C}$ and incubation for $15 \mathrm{~h}$. F, AVR9- and INF1-induced response of $C f-9^{+}$cells after transfer from 33 to $15^{\circ} \mathrm{C}$ and incubation for $15 \mathrm{~h}$. 
(Fig. 3C) also was observed in the water-treated control (data not shown).

To assay for recovery of the AVR-induced medium alkalization, cell suspensions that had been incubated for $24 \mathrm{~h}$ at $33^{\circ} \mathrm{C}$

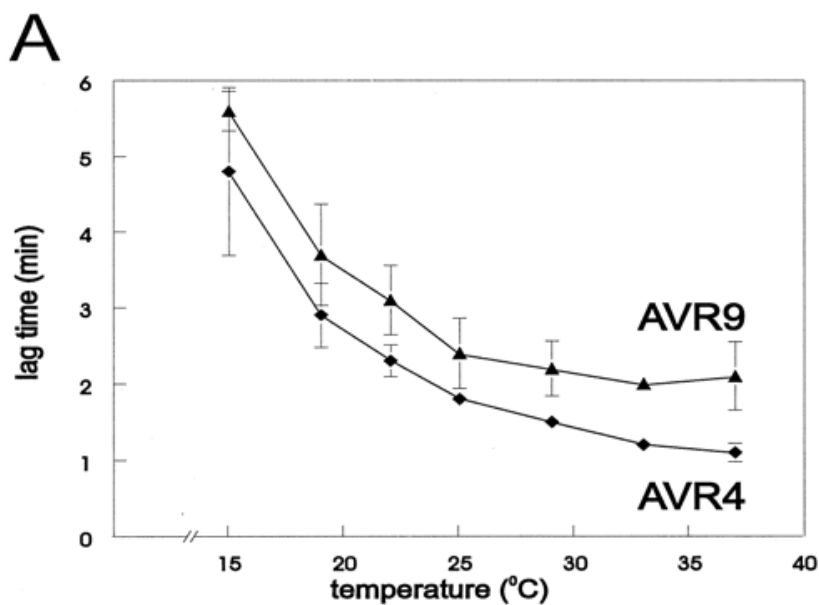

B
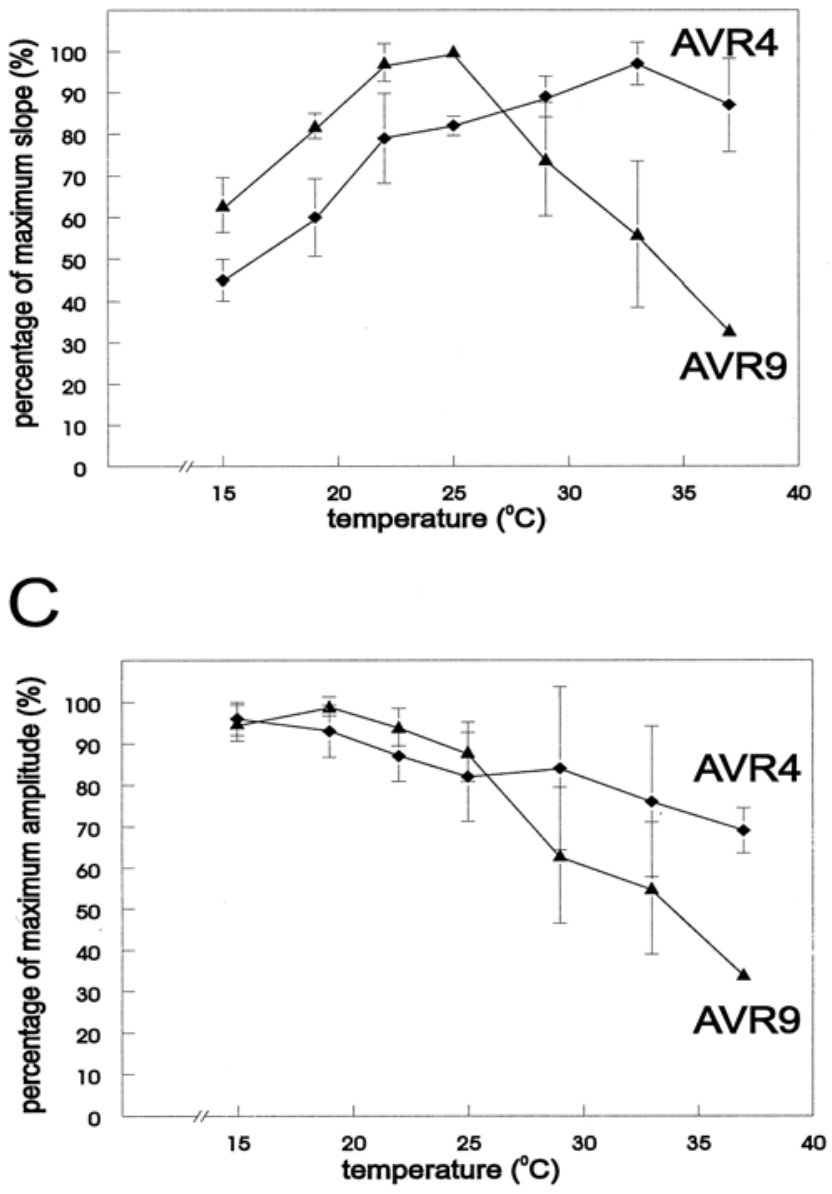

Fig. 4. Effect of temperature on the lag time, slope, and amplitude of the Cladosporium fulvum avirulence protein (AVR)-induced medium alkalization response of $\mathrm{Cf}^{+}$-tobacco cell suspensions. At 3 days after subculturing, $C f^{+}$-tobacco cell suspensions were incubated for $15 \mathrm{~h}$ at $15^{\circ} \mathrm{C}$. Subsequently, the temperature was stepwise increased to $37^{\circ} \mathrm{C}$ and, after each step, cell suspensions were treated with the matching elicitor (AVR4 $[\bullet]$ or AVR9 [ $\mathbf{A}]$ ). The graphs represent the mean data points of three independent experiments and the bars indicate their corresponding standard error. A, Lag times; B, slopes, and $\mathbf{C}$, amplitudes derived from the curves of the AVR4- and AVR9-induced medium alkalization response of $C f-4^{+}$ and $C f-9^{+}$-tobacco cell suspensions, respectively, as a function of the incubation temperature. were incubated for another $15 \mathrm{~h}$ at $15^{\circ} \mathrm{C}$ and subsequently treated with the various elicitors. For all elicitor treatments, the medium alkalization response was completely restored, demonstrating that the temperature-sensitive component of the defense-signaling pathway is located upstream of this response (Fig. 3E and F).

\section{Differences in kinetics}

between AVR4- and AVR9-induced responses.

As described above, the AVR4- and AVR9-induced medium alkalization response is completely suppressed after incubation of the cell suspensions for $24 \mathrm{~h}$ at $33^{\circ} \mathrm{C}$. To study this phenomenon in more detail, $C f^{4}$-tobacco cell suspensions were incubated at different temperatures between 15 and $37^{\circ} \mathrm{C}$, treated with elicitor and assayed for medium alkalization. To this aim, cell suspensions were preincubated for $15 \mathrm{~h}$ at $15^{\circ} \mathrm{C}$, after which the temperature of the incubator was raised stepwise to $19,22,25,29,33$, and $37^{\circ} \mathrm{C}$. At each temperature step, the cells were allowed to equilibrate for $1 \mathrm{~h}$, after which the medium alkalization induced by the matching elicitor was measured and the lag time of the response (Fig. 4A), slope (Fig. 4B), and amplitude (Fig. 4C) of the medium alkalization curve were determined (de Jong et al. 2000). The effect of the incubation temperature was quantified by setting the steepest slope of the medium alkalization curve at $100 \%$ and expressing the other slopes as a percentage of this. Upon stepwise elevation of the temperature from 15 to $33^{\circ} \mathrm{C}$, the lag time between elicitor addition and onset of medium alkalization decreased progressively (Fig. 4A). At $33^{\circ} \mathrm{C}$, the lag time was $1 \mathrm{~min}$ for AVR4 and 2 min for AVR9. The maximal slope of the AVR4induced medium alkalization curve was reached at $33^{\circ} \mathrm{C}$; whereas, for AVR9, the fastest response took place at $25^{\circ} \mathrm{C}$ (Fig. 4B). Upon elevation of the temperature, the amplitude of the AVR4- and AVR9-induced medium alkalization curve decreases (Fig. 4C), an effect which is stronger for AVR9-induced medium alkalization. These data show that, although AVR4- and AVR9-induced medium alkalization is not immediately abolished upon elevation of the temperature, differences in kinetics are apparent when the temperature sensitivity of AVR4- and AVR9-induced medium alkalization responses are compared.

\section{Medium alkalization response}

of tobacco cell suspensions is slowly suppressed at $33^{\circ} \mathrm{C}$ but recovers swiftly by lowering the temperature to $15^{\circ} \mathrm{C}$.

The experiments described above show that raising the incubation temperature of tobacco cell suspensions does not result in an acute loss of the medium alkalization response after treatment with the matching elicitor. To determine the time required to fully suppress the medium alkalization response, both $C f-4^{+}-$and $C f-9^{+}$-tobacco cell suspensions were preincubated for $15 \mathrm{~h}$ at $15^{\circ} \mathrm{C}$ and subsequently transferred to $33^{\circ} \mathrm{C}$. At different time points after transfer, $C f-4^{+}$and $C f-9^{+}$cells were treated with AVR4 and AVR9, respectively, and medium alkalization was monitored. Approximately $20 \mathrm{~h}$ after transfer to $33^{\circ} \mathrm{C}$, the AVR4-induced medium alkalization response was fully suppressed, whereas the AVR9-induced response was already fully suppressed within $15 \mathrm{~h}$ after transfer (data not shown). When the cells were preincubated at 25 instead of $15^{\circ} \mathrm{C}$, the time required to suppress the AVR4- and AVR9-induced medium alkalization response was reduced to approximately 14 and $11 \mathrm{~h}$, respectively (data not shown).

To determine the time required to regain the medium alkalization response, $C f-4^{+}-$and $C f-9^{+}-$tobacco cell suspensions cultured at $25^{\circ} \mathrm{C}$ were preincubated for $15 \mathrm{~h}$ at $33^{\circ} \mathrm{C}$ to reach full suppression of the medium alkalization response. Subsequently, the cells were treated with AVR4, AVR9, or water and incubated 
at $15^{\circ} \mathrm{C}$ in a water bath mounted on a gyratory shaker. Immediately after transfer to $15^{\circ} \mathrm{C}$, the $\mathrm{pH}$ of the extracellular medium was recorded simultaneously for both elicitor- and water-treated cell suspensions. The fluctuations in $\mathrm{pH}$, induced by the rapid change in temperature, stabilized after 20 min (Fig. 5). At approximately $45 \mathrm{~min}$ after transfer, the $\mathrm{pH}$ of the medium started to increase progressively in the elicitor-treated cells, while the $\mathrm{pH}$ of the water control remained more or less constant.

Thus, it takes 11 to $14 \mathrm{~h}$ to suppress the medium alkalization response after transfer to $33^{\circ} \mathrm{C}$, but only $45 \mathrm{~min}$ are required to regain the response upon transfer to $15^{\circ} \mathrm{C}$.

\section{Incubation of tobacco cells}

at $33^{\circ} \mathrm{C}$ decreases the number of HABS for AVR9.

The experiments described above show that the AVR-induced medium alkalization response of $C f$-transgenic tobacco cell suspensions is reversibly suppressed at $33^{\circ} \mathrm{C}$ (Fig. 3). Furthermore, all defense responses in tomato leaves and tobacco suspension cells normally induced in $C f-4 / A v r 4$ and $C f-9 / A v r 9$ plants are reversibly suppressed at $33^{\circ} \mathrm{C}$ (Fig. 2). These data suggest that, at elevated temperatures, AVR-induced signal transduction is blocked at an early step in the pathway. Earlier work by Kooman-Gersmann and associates (1996, 1998) has indicated that the HABS for AVR9 is involved in the induction of $C f-9$ mediated HR. This prompted us to investigate whether AVR9 binding to the HABS is affected at elevated temperatures.

Microsomal fractions were isolated from $C f-9^{+}-$tobacco cell suspensions that had been incubated at 20 or $33^{\circ} \mathrm{C}$ for $24 \mathrm{~h}$ and were used for standard AVR9 binding assays (KoomanGersmann et al. 1996). Strikingly, incubation of the cell suspensions at $33^{\circ} \mathrm{C}$ resulted in a $82 \%$ reduction of AVR9 binding when compared with the cells that had been incubated at $20^{\circ} \mathrm{C}$ (Table 1). To check whether decreased AVR9 binding reflects a decrease in the affinity of the HABS towards AVR9 or a decrease in the actual number of AVR9-binding sites, the binding constant $\left(\mathrm{K}_{\mathrm{d}}\right)$ was determined. The $\mathrm{K}_{\mathrm{d}}$ of the HABS from cells that had been incubated at $33^{\circ} \mathrm{C}$ was similar to that of cells incubated at $20^{\circ} \mathrm{C}$ (Table 1 ). This $\mathrm{K}_{\mathrm{d}}$ also was similar to the $\mathrm{K}_{\mathrm{d}}$ reported for the HABS isolated from tobacco leaves (KoomanGersmann et al. 1996). Furthermore, the saturation curves from which the $\mathrm{K}_{\mathrm{d}} \mathrm{s}$ were determined clearly reflected the significant decrease in the number of binding sites upon incubation at $33^{\circ} \mathrm{C}$ (data not shown). Consequently, decreased binding of AVR9 does not result from a decreased affinity of the binding site but can most likely be attributed to a decrease in the absolute number of AVR9-binding sites.

\section{DISCUSSION}

It has been known for a long time that $R$ gene-mediated resistance against pathogens can be sensitive to elevated temperatures. In recent years, several $R$ genes and their corresponding Avr genes have been cloned, some of which mediate a temperature-sensitive resistance. However, no systematic studies have been performed to determine the molecular basis underlying the temperature sensitivity of the HR. Here we show that $C f$-4- and $C f$-9-mediated defense responses are temperature-sensitive and that this sensitivity likely resides at the level of elicitor perception. Impaired resistance to $C$. fulvum at elevated temperatures has no consequences for tomato because, at higher temperatures, virulence of $C$. fulvum is significantly reduced (Small 1930).

\section{Temperature sensitivity of the HR resides at the level of elicitor perception.}

Seedlings expressing both an $A v r$ and the corresponding $C f$ resistance gene rapidly die after germination at $20^{\circ} \mathrm{C}$ but are rescued at $33^{\circ} \mathrm{C}$. Defense-related gene expression is suppressed at $33^{\circ} \mathrm{C}$, but is rapidly induced after transfer of the rescued plants to lower temperatures. This observation holds for genes either involved in HR, defense signaling, or defense responses, suggesting that the temperature-sensitive component resides early in the pathway leading to the activation of defense responses.

Even a response as early as AVR-induced medium alkalization, taking place within $5 \mathrm{~min}$ after AVR treatment of $\mathrm{Cf}^{+}-$ tobacco cell suspensions, was suppressed at elevated temperatures. Although both the AVR- and INF1-induced responses are temperature-sensitive, individual differences between the responsiveness to various elicitors become apparent at elevated temperatures. The induction of responses by INF1 was less temperature-sensitive than the AVR-induced responses (Fig. 3), whereas the AVR4- and AVR9-induced medium alkalization response was also differently affected at elevated temperatures (Fig. 4). At $20^{\circ} \mathrm{C}$, INF1 treatment results in a medium alkalization curve that is very similar to that obtained upon treatment with the AVRs at $20^{\circ} \mathrm{C}$ (results not shown). As-
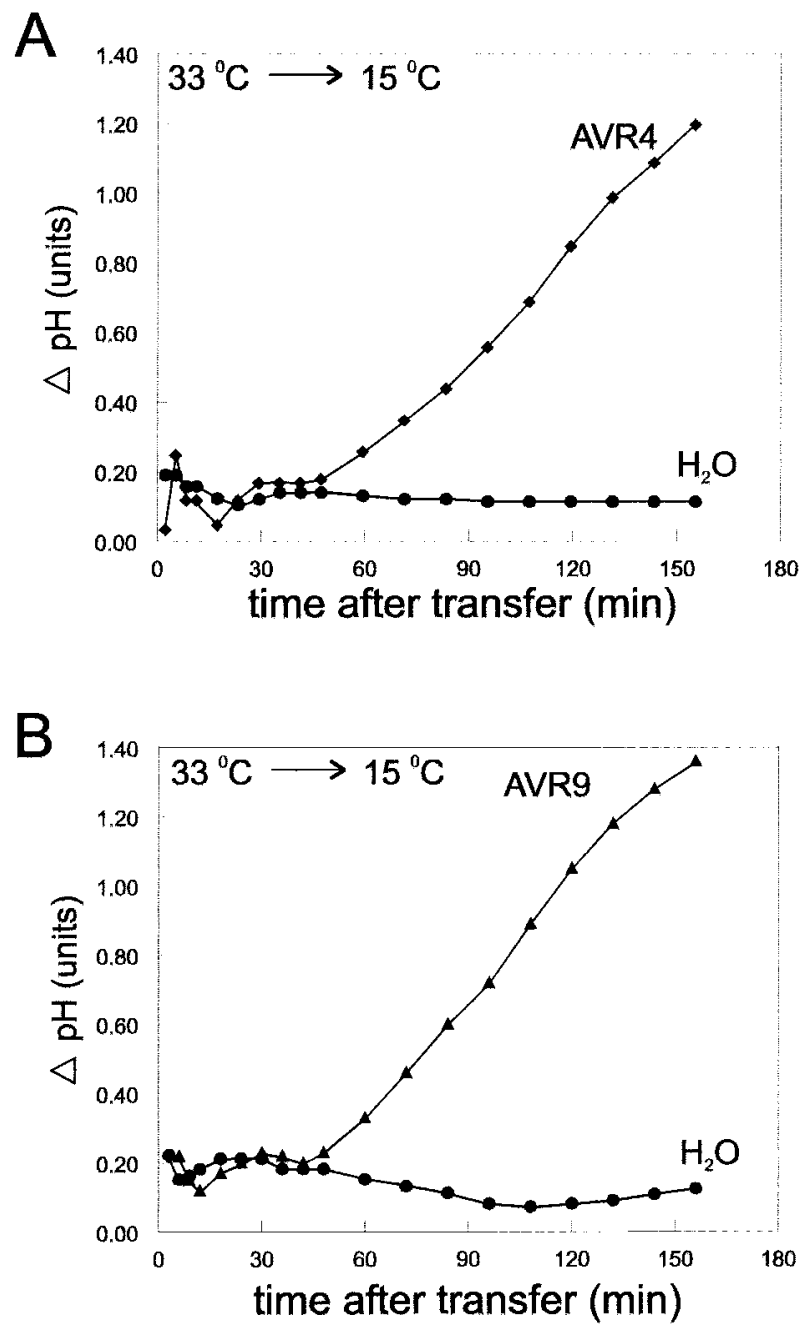

Fig. 5. Recovery of the medium alkalization response of $C f^{+}$-tobacco cell suspensions in time upon transfer from $33^{\circ} \mathrm{C}$ to $15^{\circ} \mathrm{C}$. $C f-4^{+}$- and $C f-9^{+}-$ tobacco cell suspensions were incubated for $15 \mathrm{~h}$ at $33^{\circ} \mathrm{C}$ at three days after subculturing and were treated with AVR4 $(\bullet)$ or AVR9 $(\boldsymbol{A})$, respectively, after which the temperature was instantaneously lowered to $15^{\circ} \mathrm{C}$. The $\mathrm{pH}$ of the extracellular medium was subsequently recorded in time. Control treatments consisted of addition of water $(\bullet)$ before transfer to $15^{\circ} \mathrm{C}$. A, AVR4-induced response of $C f-4^{+}$-tobacco cells upon transfer from $33^{\circ} \mathrm{C}$ to $15^{\circ} \mathrm{C}$. B, AVR9-induced response of $C f-9^{+}$-tobacco cells upon transfer from $33^{\circ} \mathrm{C}$ to $15^{\circ} \mathrm{C}$. 
suming that INF1 and AVR signaling eventually converge into the same signal transduction pathway, as challenge with these elicitors eventually results in similar responses, our observations suggest that the temperature-sensitive component of the signaling pathway resides at the level of elicitor perception. Thus, the INF1 receptor could be more stable in vivo at elevated temperatures, or display a higher affinity for INF1.

With increasing temperatures, binding of AVR9 to the HABS occurs at a higher rate (Kooman-Gersmann et al. 1996), which is in agreement with a shorter lag time of the medium alkalization response at elevated temperatures (Fig. 4A). It has been shown that, in vitro at $37^{\circ} \mathrm{C}$, the HABS remains fully stable in isolated membranes over a period of $24 \mathrm{~h}$ (KoomanGersmann et al. 1996). However, in cell suspensions, the decrease in AVR9 binding at elevated temperatures without a change in the affinity of the HABS for AVR9, reflects a decrease of the amount of AVR9 binding sites. An incubation time of $15 \mathrm{~h}$ at $33^{\circ} \mathrm{C}$ is minimally required to fully suppress AVR9-induced medium alkalization. Upon lowering of the temperature to $15^{\circ} \mathrm{C}$, the medium alkalization response was restored within $45 \mathrm{~min}$, indicating that this time span allows for production of sufficient HABS to activate downstream signal transduction. This period correlates well with the time required for de novo protein synthesis.

The stability of the HABS at $37^{\circ} \mathrm{C}$ in vitro, in contrast to the instability of this binding site at $33^{\circ} \mathrm{C}$ in vivo, suggests that in vivo the HABS is subject to an active turnover mechanism. Receptor internalization and turnover are well described in mammalian and yeast systems. For cultured mammalian cells, it has been estimated that, in some cases, membrane material equivalent to $50 \%$ of the entire cell surface is internalized every hour. This process plays a role in protein turnover, signaling and adjusting the sensitivity of a cell for a certain ligand (Munn 2001; Waterman and Yarden 2001). The decrease in the number of AVR9 HABS at elevated temperatures in vivo suggests that either their turnover increases or their de novo synthesis decreases. The latter could be the result of an increase in aberrant post-translational protein processing or assembly, or temperature-sensitive transcription of the gene or genes encoding the HABS. Possibly, the cell redirects its resources to meet the requirements of an increased metabolism caused by higher temperatures and consequently economizes on defense, suggesting that temperature sensitivity of resistance responses may be more common than previously thought. Upon incubation at lower temperatures, defense responses are rapidly restored (Fig. 5). In nature, defense responses may be slowly lost at high temperatures during daytime but will be rapidly regained during lower temperatures at night. In this way, the cell efficiently directs its resources without impairing its resistance against pathogens. Redirection of the cell's resources at elevated temperatures may be accomplished by suppression of certain transcription factors, like the ones that belong to the WRKY group and are involved in regulating plant development and defense. These factors can individually activate transcription of a group of pathogenesis-related genes by binding to W-boxes present in their promoter (Eulgem et al. 1999 and 2000; Rushton et al. 1996). Interestingly, an unusually large number of $\mathrm{W}$-box sequences were found in the promoter re-

Table 1. Specific binding of ${ }^{125}$ I-AVR9 to microsomal fractions ${ }^{\mathrm{a}}$

\begin{tabular}{lccc}
\hline Temperature $\left({ }^{\circ} \mathbf{C}\right)$ & Binding $(\mathbf{p M})$ & Binding $(\%)$ & $\mathbf{K}_{\mathbf{d}}(\mathbf{n M})$ \\
\hline 20 & $31.6 \pm 6.6$ & 100 & 0.033 \\
33 & $5.6 \pm 1.5$ & 18 & 0.051 \\
\hline
\end{tabular}

${ }^{\text {a }}$ Microsomal fractions were isolated from $C f-9^{+}$-tobacco cell suspensions incubated at 20 or $33^{\circ} \mathrm{C}$ for $24 \mathrm{~h}$. Twelve independent isolations were done for both temperatures. gion of receptor-like kinases (RLKs) in Arabidopsis spp., indicating that WRKY transcription factors may also play a regulatory role in ligand perception (Du and Chen 2000). Efforts to purify the HABS and isolate the encoding gene or genes are underway. These data will be crucial to gain further insight in the steps affected by elevated temperatures and to study receptor turnover, a subject poorly studied in plants thus far.

The Cf-9 protein is not required for AVR9 binding but is essential to initiate the signal transduction pathways leading to HR. Therefore, it would be interesting to determine whether elevated temperatures also have an effect on the $\mathrm{Cf}-9$ protein itself, because we cannot exclude the possibility that this protein is unstable under such conditions. However, we have not been able to determine the effect of elevated temperatures on the abundance or integrity of the Cf- 4 and Cf- 9 proteins themselves. Antibodies raised against $\mathrm{Cf}-9$ fail to reveal specific bands in Western blots of microsomal fractions isolated from tobacco cells expressing $C f-9$ under control of its own promoter. Tagged Cf- 9 proteins have been overexpressed in tobacco but, in such a system, it is not clear whether functional $\mathrm{Cf}$ protein or degradation products resulting from overexpression are detected by tag-directed antibodies (Benghezal et al. 2000; Piedras et al. 2000).

The $N$ gene of tobacco confers resistance against TMV by mediating recognition of the helicase domain of the TMV replicase proteins at temperatures below $28^{\circ} \mathrm{C}$. At higher temperatures, $N$-mediated HR is suppressed and the virus spreads systemically. Mutations made in the TMV replicase gene yielded viruses which could overcome $N$-mediated resistance at temperatures lower than $28^{\circ} \mathrm{C}$ but higher than $20^{\circ} \mathrm{C}$, again suggesting that temperature sensitivity resides at the level of perception. Whether this phenotype was caused by reduced affinity or reduced stability of the mutant replicase remains to be determined (Erickson et al. 1999; Padgett et al. 1997). Similar results were obtained for the $N^{\prime}$ gene, which mediates recognition of the coat protein of TMV. Mutations made in the coat protein resulted in temperature-sensitive, temperature-insensitive, and knockout phenotypes, indicating that, in this case, stability of the coat protein is affected at higher temperatures (Taraporewala and Culver 1997). Temperature-sensitive systems also are known from the field of plant development; notably, some crosses between different species result in a lethal phenotype that may be rescued at higher temperatures. Recently, Yamada and associates (2000) demonstrated that seedlings and calli resulting from a cross between Nicotiana suavolens and $N$. tabacum die due to the systemic initiation of programmed cell death. This lethal phenotype could be overcome by a temperature of $36^{\circ} \mathrm{C}$. In this system, the direct cause of the temperature sensitivity is not known.

\section{Application of the temperature sensitivity of defense responses in further research.}

The discovery that $C f / A v r$-induced HR is temperature sensitive offers great opportunities to study the signal transduction pathway eventually leading to HR and resistance in intact plants. Synchronization of the initiation of the defense response of the plant is a prerequisite to identify the genes that orchestrate the initiation of the HR shortly after elicitor perception. So far, tobacco cell suspensions expressing a $C f$ gene have been the best system available. For example, Durrant and associates (2000) treated $C f-9^{+}-$tobacco cell suspensions with AVR9 and determined differential gene expression employing cDNA-amplified fragment length polymorphism (AFLP) analysis. In addition to genes involved in the defense response, genes involved in wound responses also were identified. As mentioned before, many defense-related genes are constitutively transcribed in suspension cultures, which is a disadvantage of this system. Furthermore, AVR9-induced cell death did not occur in these cell 
suspensions. Probably the amount of AVR9 that was added to the cells was not sufficient to reach the threshold required for execution of the HR.

We now are able to synchronize the initiation of the HR in intact tomato plants by exploiting the temperature sensitivity of CflAvr-mediated responses. To this aim, seedlings containing both a $C f$ gene and the matching $A v r$ gene are grown at an elevated temperature and subsequently transferred to $20^{\circ} \mathrm{C}$, provoking a synchronous and systemic initiation of the HR. We are currently analyzing cDNAs that have been identified by differential cDNA-AFLP analysis of RNA isolated at distinct time points after the temperature shift. Differential cDNA-AFLP analysis, in combination with functionality tests of the identified cDNAs by functional genomics, should be an ideal approach to identify the key players that orchestrate the activation of early plant defense responses.

\section{MATERIALS AND METHODS}

\section{Preparation of elicitors.}

Race-specific elicitor AVR9 of C. fulvum was chemically synthesized and the correctly folded product was purified by highperformance liquid chromatography according to the procedure described by Mahé and associates (1998). Race-specific elicitor AVR4 of $C$. fulvum was produced by the yeast Pichia pastoris (Invitrogen, Groningen, The Netherlands) and purified from the culture filtrate (Van den Burg et al. 2001). INF1 was purified from culture filtrate of Phytophthora infestans, isolate 880069 , grown on modified liquid Plich medium at $18^{\circ} \mathrm{C}$ for 3 weeks (Van der Lee et al. 1997). Briefly, $500 \mathrm{ml}$ of culture filtrate was freeze dried, dissolved in $20 \mathrm{ml}$ of water, and dialyzed overnight against water at $4^{\circ} \mathrm{C}$. After freeze-drying, the lyophilisate was dissolved in $9 \mathrm{ml}$ of elution buffer $(50 \mathrm{mM}$ Tris- $\mathrm{HCl}, \mathrm{pH} 7.5$, $100 \mathrm{mM} \mathrm{NaCl}$ ) and centrifuged at $13,000 \times g$ for $15 \mathrm{~min}$. The supernatant was loaded on a Sephadex G-50 (Amersham Pharmacia Biotech, Uppsala, Sweden) column (2.6 by $100 \mathrm{~cm})$, equilibrated with elution buffer. The column was eluted at $4^{\circ} \mathrm{C}$ at a flow rate of $9 \mathrm{ml}$ for $20 \mathrm{~h}$. The eluate was monitored at 280 $\mathrm{nm}$ and $4.5-\mathrm{ml}$ fractions were collected. Samples were taken from the different fractions, based on the UV absorption profile, and analyzed by sodium dodecyl sulfate-polyacrylamide gel electrophoresis (SDS-PAGE). To assay for biological activity, $0.5-\mathrm{ml}$ aliquots from fractions containing proteins with a molecular mass of approximately $10 \mathrm{kDa}$ were desalted on an NAP-5 column (Amersham Pharmacia Biotech, Uppsala, Sweden), after which they were injected into leaves of $N$. tabacum cv. Petit Havana SR1 or tomato (Lycopersicon esculentum). Fractions inducing necrosis in tobacco but not in tomato were pooled, dialyzed against water, and freeze dried. The lyophilisate was dissolved in $1 \mathrm{ml}$ of $10 \%$ acetonitrile $(\mathrm{ACN})$ and $0.1 \%$ trifluoroacetic acid (TFA) in water and centrifuged at $13,000 \times g$ for $15 \mathrm{~min}$. From the supernatant, $200-\mu$ l aliquots were loaded on a ProRPC HR 5/10 reversed-phase column (Amersham Pharmacia Biotech) and the column was eluted at a flow rate of $0.3 \mathrm{ml} / \mathrm{min}$, applying a gradient ranging from 10 to $40 \% \mathrm{ACN}$ in water, containing $0.1 \%$ TFA, over a period of $70 \mathrm{~min}$. The eluate was monitored at $280 \mathrm{~nm}$ and 0.6-ml fractions were collected. Based on the UV absorption profile, fractions containing protein were freeze dried and analyzed both by SDS-PAGE and injection into leaves of tobacco and tomato. Fractions that contained pure INF1 were collected from several runs, pooled, and freeze dried. The lyophilisate was dissolved in $10 \% \mathrm{ACN}$ in water to a final concentration of $10 \mathrm{mg} / \mathrm{ml}$ and stored at $-20^{\circ} \mathrm{C}$ until further use.

\section{Cultivation of plants.}

Plants were grown under normal greenhouse conditions, unless stated otherwise. To synchronize germination, tomato seed were treated with $20 \%$ Glorix in water for 20 min and then thoroughly rinsed with water, prior to sowing. Germination took place under normal greenhouse conditions, after which plants were transferred to temperature-controlled incubators (Elbanton, Kerkdriel, The Netherlands) at a regime of $16 \mathrm{~h}$ light and $8 \mathrm{~h}$ dark.

Crosses between $\boldsymbol{A v r}$ - and $\boldsymbol{C} \boldsymbol{f}$-expressing tomato plants.

Crosses between Avr4- and Avr9-expressing MM-Cf0 plants and MM-Cf4 and MM-Cf9 plants, respectively, were performed as described earlier (Cai et al. 2001; HammondKosack et al. 1994; Thomas et al. 1997).

\section{Transformation of tobacco.}

The $C f-4$ gene was transferred to $N$. tabacum cv. Petit Havana SR1 using the genomic $C f-4 P s t$ I fragment of $5.8 \mathrm{kbp}$ (Thomas et al. 1997) ligated into the pCGN1548 binary vector (McBride and Summerfelt 1990). Transformation was performed according to standard procedures. Transgenic plants were assayed for AVR4-specific necrosis by expression of Avr4 in leaf sectors by agroinfiltration (Van der Hoorn et al. 2000). Responding plants were selfed and the resulting seed were sterilized in $20 \%$ Glorix and transferred to MS medium (Murashige and Skoog 1962), supplemented with sucrose at 10 $\mathrm{g} /$ liter and kanamycin at $100 \mathrm{mg} / \mathrm{ml}$. After germination, transformed lines showing a 3:1 segregation for resistance to kanamycin were selected and kanamycin-resistant plants were transferred to the greenhouse. The plants were selfed, after which homozygous ones were identified by sowing the seed on kanamycin-containing medium. Eventually, seven lines were identified that showed both 3:1 segregation for resistance to kanamycin and AVR4-specific necrosis after Avr4 agroinfiltration. $C f-9^{+}$N. tabacum cv. Petit Havana SR1 plants have been described previously (de Jong et al. 2000).

\section{Initiation and cultivation of tobacco cell suspensions.}

Cell suspensions from $C f-4^{+}$and $C f-9^{+} N$. tabacum cv. Petit Havana SR1 were initiated and cultivated as described previously (de Jong et al. 2000). Briefly, callus was induced on explants of transgenic tobacco specifically responding to AVR4 or AVR9 and transferred to 300-ml Erlenmeyer flasks, containing $50 \mathrm{ml}$ of liquid MS medium (Murashige and Skoog 1962), supplemented with Gamborg B5 vitamin mixture (Gamborg et al. 1968), 2,4-dichlorophenoxyacetic acid at $1 \mathrm{mg} /$ liter, and kinetin at $0.1 \mathrm{mg} /$ liter. The flasks were incubated in the dark at $110 \mathrm{rpm}$ on a rotary shaker at $25^{\circ} \mathrm{C}$ and the resulting cell suspensions were assayed for AVR4- or AVR9-induced medium alkalization (see below). From responding cell suspensions growing in the log phase, 8-ml aliquots were transferred to fresh medium weekly and cultured at $25^{\circ} \mathrm{C}$.

\section{Medium alkalization and oxidative burst assay.}

Three days after transfer to fresh medium, several cell suspensions were pooled and mixed to obtain the total volume of cells required for an experiment. The cells were distributed over $25-\mathrm{ml}$ sterile Erlenmeyer flasks, in 7.5-ml aliquots. The flasks were closed with a cotton plug and were preincubated on a rotary shaker at $220 \mathrm{rpm}$ at the required temperature. While shaking, medium alkalization was recorded by immersion of a mini $\mathrm{pH}$ electrode (InLab 423, Mettler Toledo, Tiel, The Netherlands) into the cell suspension and subsequent addition of elicitor to the medium. Elicitors were added to a final concentration of $0.32 \mu \mathrm{M}$, a concentration that elicits a maximal medium alkalization response at $20^{\circ} \mathrm{C}$ (de Jong et al. 2000). For measurements of the medium alkalization response at different temperatures, the $\mathrm{pH}$ electrode was calibrated for each temperature at which the response was determined. 
Oxidative burst assays were performed as described previously (de Jong et al. 2000) and viability of the cells that had been incubated at elevated temperatures was checked as described by Oparka and Read (1994).

\section{RNA extraction and RNA gel blot analysis.}

After germination under normal greenhouse conditions, $C f$ $4 / A v r 4$ and $C f-9 / A v r 9$ seedlings and corresponding control seedlings were incubated at $33^{\circ} \mathrm{C}$ for 2 weeks. The plants were subsequently transferred to $20^{\circ} \mathrm{C}$ and RNA was isolated at $0,1,4,8$, 12,24 , and $36 \mathrm{~h}$ after this temperature shift. The expression of three classes of defense-related genes was analyzed as described by Cai and associates (2001). Expression levels of the HR-related gene LeHsr203 (Pontier et al. 1998) and genes encoding proteins involved in defense signaling, such as CDPK (Ganal et al. 1998; Romeis et al. 2000), NPRl, (Cao et al. 1997), and ACC-oxidase (ACCOX) (Fluhr and Mattoo 1996) were determined. Furthermore, the expression levels of genes encoding proteins involved in defense responses, such as P69A (Meichtry et al. 1999), lipid transfer protein (LTP) (Van Loon and Van Strien 1999), acidic and basic chitinase (ChiA and ChiB, respectively), (Danhash et al. 1993) and acidic and basic glucanase (GluA and $G l u B$, respectively) (Van Kan et al. 1992) were determined. In tobacco, the Hinl gene is used as a marker for HR. This gene is highly expressed in incompatible interactions between the plant-pathogenic bacterium Pseudomonas syringae and tobacco, but not in compatible interactions (Gopalan et al. 1996). All molecular procedures were performed as described by Sambrook and associates (1989). Total RNA was isolated according to the Extract-A-Plant RNA isolation protocol (Clontech Laboratories, Palo Alto, CA, U.S.A.). Total RNA (10 $\mu \mathrm{g})$ was separated on a $1.2 \%$ agarose gel containing formaldehyde and blotted onto Hybond $\mathrm{N}^{+}$membrane (Amersham Pharmacia Biotech), according to the manufacturer's instructions. Hybridization of RNA gel blots was performed overnight with ${ }^{32} \mathrm{P}$-labeled cDNA probes at $65^{\circ} \mathrm{C}$ in $0.30 \mathrm{M} \mathrm{Na}_{2} \mathrm{HPO}_{4}, 0.14 \mathrm{M} \mathrm{NaH}_{2} \mathrm{PO}_{4}, 1$ $\mathrm{mM}$ EDTA, and 7\% (wt/vol) SDS. The cDNA fragments that were used as probes have been described previously (Cai et al. 2001). Membranes were washed at $65^{\circ} \mathrm{C}$ in $0.5 \%$ SSC (1× SSC is $0.15 \mathrm{M} \mathrm{NaCl}$ plus $0.015 \mathrm{M}$ sodium citrate) containing $0.1 \%$ SDS and a KODAK X-AR film was exposed to the blot.

\section{Isolation of microsomal fractions.}

In three independent experiments, at 3 days after subculturing, four $C f-9^{+}-$tobacco cell suspension cultures were incubated for $24 \mathrm{~h}$ at either 33 or at $20^{\circ} \mathrm{C}$. An aliquot of the cell suspensions was subsequently assayed for AVR9-induced medium alkalization and the remaining cells were used to isolate microsomal fractions. Microsomal fractions were isolated as described by KoomanGersmann and associates (1996). Briefly, cells were harvested by passing the cell suspension over a Büchner funnel, after which they were rinsed three times with water and frozen in liquid nitrogen. Cells were thawed in membrane extraction buffer (10 mM Tris-HCl, pH 7.5, 3 mM EDTA, $0.25 \mathrm{mM}$ sucrose) and homogenized in a Waring blender. The homogenate was squeezed through Miracloth, the filtrate was centrifuged at $10,000 \times g$ for $10 \mathrm{~min}$, and the supernatant was subsequently centrifuged at $100,000 \times g$ for $30 \mathrm{~min}$. The resulting microsomal fraction was resuspended in $10 \mathrm{mM}$ Tris- $\mathrm{HCl}, \mathrm{pH} 7.5$, and 0.25 $\mathrm{mM}$ sucrose and was divided into $50-\mu \mathrm{l}$ aliquots that were stored at $-80^{\circ} \mathrm{C}$ until further use. The protein content of the different microsomal fractions was determined with a BCA protein determination kit (Pierce, Rockford, IL, U.S.A.) according to the manufacturer's instructions. Binding studies were performed with ${ }^{125}$ I-radiolabeled AVR9 on microsomal fractions containing 48- $\mu \mathrm{g}$ protein equivalents following the procedure as described earlier (Kooman-Gersmann et al. 1996).

\section{ACKNOWLEDGMENTS}

This work was supported by the Dutch Foundation for Earth and Life Sciences (ALW) (award SLW 805.45.001 to C. F. de Jong), IFS (Sweden), the China Scholarship Council (CSC), the Ministry of Education of China, the China National Natural Science Foundation, Wageningen University (awards no. C/2666-1, 39670487 and 30070492 to X. Cai), Keygene N.V., the Netherlands and the European Commission, DGXII/E (award no. ERBBIO4-CT96-0515 to F. L. W. Takken). We thank R. Van der Hoorn for critically reading the manuscript and $\mathrm{H}$. Van den Burg for purification of AVR4 and AVR9.

\section{LITERATURE CITED}

Benghezal, M., Wasteneys, G. O., and Jones, D. A. 2000. The C-terminal dilysine motif confers endoplasmic reticulum localization to type I membrane proteins in plants. Plant Cell 12:1179-1201.

Bent, A. F. 1996. Plant disease resistance genes-function meets structure. Plant Cell 8:1757-1771.

Bonas, U., and Van den Ackerveken, G. F. J. M. 1999. Gene-for-gene interactions: Bacterial avirulence proteins specify plant disease resistance. Curr. Opin. Microbiol. 2:94-98.

Cai, X., Takken, F. L. W., Joosten, M. H. A. J., and De Wit, P. J. G. M. 2001. Specific recognition of AVR4 and AVR9 results in distinct patterns of hypersensitive cell death in tomato. Mol. Plant Pathol. 2:77-86.

Cao, H., Glazebrook, J., Clarke, J. D., Volko, S., and Dong, X. N. 1997. The Arabidopsis NPR1 gene that controls systemic acquired resistance encodes a novel protein containing ankyrin repeats. Cell 88:57-63.

Danhash, N., Wagemakers, C. A. M., Van Kan, J. A. L., and De Wit, P. J. G. M. 1993. Molecular characterization of four cDNAs obtained from Cladosporium fulvum-infected tomato. Plant Mol. Biol. 22:1017-1029.

de Jong, C. F., Honée, G., Joosten, M. H. A. J., and De Wit, P. J. G. M 2000. Early defense responses induced by AVR9 and mutant analogues in tobacco cell suspensions expressing the $C f-9$ resistance gene. Physiol. Mol. Plant. Pathol. 56:169-177.

Dixon, M. S., Jones, D. A., Keddie, J. S., Thomas, C. M., Harrison, K., and Jones, J. D. G. 1996. The tomato $C f$-2 disease resistance locus comprises two functional genes encoding leucine-rich repeat proteins. Cell 84:451-459.

Dixon, R. A., Harrison, M. J., and Lamb, C. J. 1994. Early events in the activation of plant responses. Annu. Rev. Phytopathol. 32:479-501.

Dropkin, V. H. 1969. The necrotic reaction of tomatoes and other hosts resistant to Meloidogyne: Reversal by temperature. Phytopathology 59:1632-1637.

Du, L., and Chen, Z. 2000. Identification of genes encoding receptor-like protein kinases as possible targets of pathogen- and salicylic acid-induced WRKY DNA-binding proteins in Arabidopsis. Plant J. 24:837-847.

Durrant, W. E., Rowland, O., Piedras, P., Hammond-Kosack, K. E., and Jones, J. D. G. 2000. cDNA-AFLP reveals a striking overlap in racespecific resistance and wound response gene expression profiles. Plant Cell 12:963-977.

Erickson, F. L., Holzberg, S., Calderon-Urrea, Handley, V., Axtell, M., Corr, C., and Baker, B. 1999. The helicase domain of the TMV replicase proteins induces the $N$-mediated defense response in tobacco. Plant J. 18:67-75.

Eulgem, T., Rushton, P. J., Robatzek, S., and Somssich, I. E. 2000. The WRKY superfamily of plant transcription factors. Trends Plant Sci. 5:199-206.

Eulgem, T., Rushton, P. J., Schmelzer, E., Hahlbrock, K., and Somssich, I. E. 1999. Early nuclear events in plant defense signaling: Rapid gene activation by WRKY transcription factors. EMBO (Eur. Mol. Biol. Organ.) J. 18:4689-4699.

Flor, H. H. 1942. Inheritance of pathogenicity in Melampsora lini. Phytopathology 32:653-669.

Fluhr, R., and Mattoo, A. K. 1996. Ethylene, biosynthesis and perception. Crit. Rev. Plant Sci. 15:479-513.

Gamborg, O. L., Miller, R. A., and Ojima, K. 1968. Nutrient requirements of suspension cultures of soybean root cells. Exp. Cell Res. 50:151.

Ganal, M. W., Czihal, R., Hannappel, U., Kloos, D., Polley, A., and Ling, H. 1998. Sequencing of cDNA clones from the genetic map of tomato (Lycopersicon esculentum). Genome Res. 8:842-847.

Gopalan, S., Wei, W., and He, S. Y. 1996. Hrp gene-dependent induction of hin1: A plant gene activated rapidly by both harpins and the avrPto gene-mediated signal. Plant J. 10:591-600.

Hammond-Kosack, K. E., Harrison, K., and Jones, J. D. 1994. Developmentally regulated cell death on expression of the fungal avirulence gene Avr 9 in tomato seedlings carrying the disease resistance gene $C f-9$. Proc. Natl. Acad. Sci. U.S.A. 91:10445-10449.

Hammond-Kosack, K. E., and Jones, J. D. G. 1997. Plant disease resis- 
tance genes. Annu. Rev. Plant Physiol. Plant Mol. Biol. 48:575-607.

Hammond-Kosack, K. E., Tang, S., Harrison, K., and Jones, J. D. G. 1998. The tomato $C f-9$ disease resistance gene functions in tobacco and potato to confer responsiveness to the fungal avirulence gene product AVR9. Plant Cell 10:1251-1266.

Honée, G., Buitink, J., Jabs , T., De Kloe, J., Sijbolts, F., Apotheker, M., Weide, R., Sijen, T., Stuiver, M., and De Wit , P. J. G. M. 1998. Induction of defense-related responses in Cf9 tomato cells by the AVR9 elicitor peptide of Cladosporium fulvum is developmentally regulated. Plant Physiol. 117:809-820.

Jia, Y., McAdams, S. A., Bryan, G. T., Hershey, H. P., and Valent, B. 2000 Direct interaction of resistance gene and avirulence gene products confers rice blast resistance. EMBO (Eur. Mol. Biol. Organ.) J. 19:4004-4014.

Jones, D. A., and Jones, J. D. G. 1997. The roles of leucine-rich repeat proteins in plant defenses. Adv. Bot. Res. Inc. Adv. Plant Pathol. 24:89-167.

Jones, D. A., Thomas, C. M., Hammond-Kosack, K. E., Balint-Kurti, P. J., and Jones, J. D. G. 1994. Isolation of the tomato Cf-9 gene for resistance to Cladosporium fulvum by transposon tagging. Science 266:789-793.

Joosten, M. H. A. J., Cozijnsen, A. J., and De Wit, P. J. G. M. 1994. Host resistance to a fungal tomato pathogen lost by a single base-pair change in an avirulence gene. Nature 367:384-386.

Joosten, M. H. A. J., and De Wit, P. J. G. M. 1999. The tomato-Cladosporium fulvum interaction: A versatile experimental system to study plantpathogen interactions. Annu. Rev. Phytopathol. 37:335-367.

Kamoun, S., Van West, P., Vleeshouwers, V. G. A. A., De Groot, K. E., and Govers, F. 1998. Resistance of Nicotiana benthamiana to Phytophthora infestans is mediated by the recognition of the elicitor protein INF1. Plant Cell 10:1413-1426.

Kawchuk, L. M., Hachey, J., Lynch, D. R., Kulscar, F., Rooijen, G., Waterer, D. R., Robertson, A., Kokko, E., Byers, R., Howard, R. J., Fischer, R., and Prüfer, D. 2001. Tomato Ve disease resistance genes encode cell surfacelike receptors. Proc. Natl. Acad. U.S.A. 98:6511-6515.

Kooman-Gersmann, M., Honée, G., Bonnema, G., and De Wit, P. J. G. M 1996. A high-affinity binding site for the Avr9 peptide elicitor of Cladosporium fulvum is present on plasma membranes of tomato and other solanaceous plants. Plant Cell 8:929-938.

Kooman-Gersmann, M., Vogelsang, R., Vossen, P., Van den Hooven, H W., Mahé, E., Honée, G., and De Wit, P. J. G. M. 1998. Correlation between binding affinity and necrosis-inducing activity of mutant AVR9 peptide elicitors. Plant Physiol. 117:609-618.

Laugé, R., and De Wit, P. J. G. M. 1998. Fungal avirulence genes: Structure and possible functions. Fungal Genet. Biol. 24:285-297.

Loegering, W. Q., and Giss, J. R. 1957. Independence in the action of three genes conditioning stem rust resistance in Red Egyptian wheat. Phytopathology 47:740-741.

Luderer, R., Rivas, S., Nürnberger, T., Mattei, B., Van den Hooven, H. W., Van der Hoorn, R. A. L., Romeis, T., Wehrfritz, J.-M., Blume, B., Nennstiel, D., Zuidema, D., Vervoort, J., De Lorenzo, G., Jones, J. D. G., De Wit, P. J. G. M., and Joosten, M. H. A. J. 2001. No evidence for binding between resistance gene product AVR9 of tomato and avirulence gene product AVR9 of Cladosporium fulvum. Mol. Plant-Microbe Interact. 14:867-876.

Luderer, R., Takken, F. L. W., De Wit, P. J. G. M., and Joosten, M. H. A. J. 2002. Cladosporium fulvum overcomes $C f-2$-mediated resistance by producing truncated AVR2 elicitor proteins. Mol. Microbiol. 45:875-884.

Mahé, E., Vossen, P., Van den Hooven, H. W., Le Nguyen, D., Vervoort, J., and De Wit, P. J. G. M. 1998. Solid-phase synthesis, conformational analysis and biological activity of AVR9 elicitor peptides of the fungal pathogen Cladosporium fulvum. J. Pept. Res. 52:482-494.

May, M. J., Hammond-Kosack, K. E., and Jones, J. D. G. 1996. Involvement of reactive oxygen species, glutathione metabolism, and lipid peroxidation in the $C f$-gene-dependent defense response of tomato cotyledons induced by race-specific elicitors of Cladosporium fulvum. Plant Physiol. 110:1367-1379.

McBride, K. E., and Summerfelt, K. R. 1990. Improved binary vectors for Agrobacterium-mediated plant transformation. Plant Mol. Biol. 14:269276

Meichtry, J., Amrhein, N., and Schaller, A. 1999. Characterization of the subtilase gene family in tomato (Lycopersicon esculentum Mill.). Plant Mol. Biol. 39:749-760.

Munn, L. 2001. Molecular requirements for the internalization step of endocytosis: Insights from yeast. Biochim. Biophys. Acta 1535:236-257.

Murashige, T., and Skoog, F. 1962. A revised medium for rapid growth and bioassays with tobacco tissue cultures. Physiol. Plant. 15:473.

Oparka, K. J., and Read, N. D. 1994. The use of fluorescent probes for studies of living plant cells. Pages 27-50 in: Plant Cell Biology, A Practical Approach. N. Harris and K. J. Oparka, eds. Oxford University Press, Oxford.
Padgett, H. S., Watanabe, Y., and Beachy, R. N. 1997. Identification of the TMV replicase sequence that activates the $N$ gene-mediated hypersensitive response. Mol. Plant-Microbe Interact. 10:709-715.

Piedras, P., Hammond-Kosack, K. E., Harrison, K., and Jones, J. D. G. 1998. Rapid, $C f-9$ - and Avr9-dependent production of active oxygen species in tobacco suspension cultures. Mol. Plant-Microbe Interact. 11:1155-1166.

Piedras, P., Rivas, S., Dröge, S., Hillmer, S., and Jones, J. D. G. 2000 Functional c-myc-tagged $C f-9$ resistance gene products are plasmamembrane localized and glycosylated. Plant J. 21:529-536.

Pontier, D., Tronchet, M., Rogwosky, P., Lam, E., and Roby, D. 1998. Activation of $h s r 203$, a plant gene expressed during incompatible plantpathogen interactions, is correlated with programmed cell death. Mol. Plant-Microbe Interact. 11:544-554.

Romeis, T., Piedras, P., and Jones, J. D. G. 2000. Resistance gene-dependent activation of a calcium-dependent protein kinase in the plant defense response. Plant Cell 12:803-815.

Romeis, T., Piedras, P., Zhang, S. Q., Klessig, D. F., Hirt, H., and Jones, J. D. G. 1999. Rapid AVR9- and Cf-9-dependent activation of MAP kinases in tobacco cell cultures and leaves: Convergence of resistance gene, elicitor, wound, and salicylate responses. Plant Cell 11:273-287.

Rushton, P. J., Torres, J. T., Parniske, M., Wernert, P., Hahlbrock, K., and Somssich, I. E. 1996. Interaction of elicitor-induced DNA-binding proteins with elicitor response elements in the promoters of parsley PR1 genes. EMBO (Eur. Mol. Biol. Organ.) J. 15:5690-5700.

Sambrook, J., Fritsch, E. F., and Maniatis, T., T. 1989. Molecular Cloning: A Laboratory Manual, 2nd ed., vol. 2. Cold Spring Harbor Laboratory Press, Cold Spring Harbor, NY, U.S.A

Samuel, G. 1931. Some experiments on inoculation methods with plant viruses, and on local lesions. Ann. Appl. Biol. 18:494-507.

Small, T. 1930. The relation of atmospheric temperature and humidity to tomato leaf mold (Cladosporium fulvum). Ann. Appl. Biol. 17:71-80.

Takken, F. L. W., and Joosten, M. H. A. J. 2000. Plant resistance genes: Their structure, function and evolution. Eur. J. Plant Pathol. 106:699-713.

Takken, F. L. W., Schipper, D., Nijkamp, H. J. J., and Hille, J. 1998. Identification and $D s$-tagged isolation of a new gene at the $C f-4$ locus of tomato involved in disease resistance to Cladosporium fulvum race 5 . Plant J. 14:401-411.

Tang, X. Y., Frederick, R. D., Zhou, J. M., Halterman, D. A., Jia, Y. L., and Martin, G. B. 1996. Initiation of plant disease resistance by physical interaction of AvrPto and Pto kinase. Science 274:2060-2063.

Taraporewala, Z. F., and Culver, J. N. 1997. Structural and functional conservation of the tobamovirus coat protein elicitor active site. Mol Plant-Microbe Interact. 10:597-604.

Thomas, C. M., Jones, D. A., Parniske, M., Harrison, K., Balint-Kurti, P. J., Hatzixanthis, K., and Jones, J. D. G. 1997. Characterization of the tomato $C f-4$ gene for resistance to Cladosporium fulvum identifies sequences that determine recognitional specificity in $C f-4$ and $C f-9$. Plant Cell 9:2209-2224.

Van den Burg, H. A., De Wit, P. J. G. M., and Vervoort, J. 2001. Efficient ${ }^{13} \mathrm{C} /{ }^{15} \mathrm{~N}$ double labeling of the avirulence protein AVR4 in a methanolutilizing strain $\left(\mathrm{Mut}^{+}\right.$) of Pichia pastoris. J. Biol. NMR 20:251-261.

Van der Hoorn, R. A. L., Laurent, F., Roth, R., and De Wit, P. J. G. M. 2000. Agroinfiltration is a versatile tool that facilitates comparative analyses of $A v r 9 / C f$-9-induced and $A v r 4 / C f$-4-induced necrosis. Mol. Plant-Microbe Interact. 13:439-446.

Van der Lee, T., De Witte, I., Drenth, A., Alfonso, C., and Govers, F. 1997. AFLP linkage map of the oomycete Phytophthora infestans. Fungal Genet. Biol. 21:278-291

Van Kan, J. A. L., Joosten, M. H. A. J., Wagemakers, C. A. M., Van den Berg-Velthuis, G. C. M., and De Wit, P. J. G. M. 1992. Differential accumulation of mRNAs encoding extracellular and intracellular PR proteins in tomato induced by virulent and avirulent races of Cladosporium fulvum. Plant Mol. Biol. 20:513-527.

van Kan, J. A. L., van den Ackerveken, G. F. J. M., and De Wit, P. J. G. M. 1991. Cloning and characterization of cDNA of avirulence gene Avr9 of the fungal pathogen Cladosporium fulvum, causal agent of tomato leaf mold. Mol. Plant-Microbe Interact. 4:52-59.

Van Loon, L. C., and Van Strien, E. A. 1999. The families of pathogenesisrelated proteins, their activities, and comparative analysis of PR-1 type proteins. Physiol. Mol. Plant Pathol. 55:85-97.

Waterman, H., and Yarden, Y. 2001. Molecular mechanisms underlying endocytosis and sorting of ErbB receptor tyrosine kinases. FEBS (Fed. Eur. Biochem. Soc.) Lett. 490:142-152.

Yamada, T., Marubashi, W., and Niwa, M. 2000. Apoptotic cell death induces temperature-sensitive lethality in hybrid seedlings and calli derived from the cross of Nicotiana suaveolens $\times N$. tabacum. Planta 211:614-622. 